\title{
Synthesis and Biodegradability of Copolymers of Ethylene Carbonate with Lactones
}

\author{
Hiroyuki SHIRAHAMA $^{\dagger}$, Akinori KANETANI, and Hajime YASUDA ${ }^{\dagger}$ \\ Department of Applied Chemistry, Faculty of Engineering, Hiroshima University, \\ 1-4-1 Kagamiyama, Higashi-Hiroshima 739-8527, Japan
}

(Received September 30, 1999)

\begin{abstract}
The copolymers of ethylene carbonate (EC) with $\varepsilon$-caprolactone (CL) or $\delta$-valerolactone (VL) were synthesized using $\left(\mathrm{C}_{5} \mathrm{Me}_{5}\right)_{2} \mathrm{SmMe}(\mathrm{THF})$ as initiator. We prepared EC/CL and EC/VL copolymers with a high molecular weight $\left(M_{n} \geqq 140000\right)$ without decarboxylation from the EC unit. The EC/CL copolymers were obtained in a higher carbonate content (up to $c a .30 \mathrm{~mol} \%$ ) and in a better yield compared with EC/VL copolymers. The ${ }^{1} \mathrm{H}$ NMR and thermal analyses revealed that these copolymers exhibit random arrangement. The enzymatic degradations of EC/lactone copolymers were investigated using lipoprotein lipase and cholesterol esterase (both from Pseudomonas sp.). The degradability of the copolymers was much improved compared with that of lactone homopolymers. Greater degradation was observed for the lipase-induced degradation than the cholesterol esterase. The biodegradability of these copolymers in natural environments (viz., in activated sludge and seawater) was examined. As compared with enzymatic degradations, similar good biodegradability was observed for EC/CL copolymers, while a poor degradation was seen for EC/VL copolymers.
\end{abstract}

KEY WORDS Ethylene Carbonate / Lactone / Copolymer / Sm ( II ) Complex / Biodegradation /

In general, polycarbonates refer to an aromatic one prepared by polycondensation of bisphenol A and phosgene. This aromatic polycarbonate is utilized as engineering plastic, compact discs, etc. due to its high mechanical properties and transparency. Few applications of aliphatic polycarbonates have hitherto been investigated because of their low melting temperatures and low crystallinity.

Aliphatic polycarbonates are usually obtained by polycondensation of diols with dialkyl carbonates, but their molecular weights are lower than ca. 5000 without transesterification. ${ }^{1}$ In recent years, the ring-opening polymerization of cyclic carbonates has been adopted to obtain higher molecular-weight polymers. ${ }^{2-7}$ Mainly, five to seven-membered rings are known as cyclic carbonate. Among these, six-membered cyclic carbonates such as trimethylene carbonate (TMC) and 2,2-dimethyl trimethylene carbonate (DTC) are often used for their ease of polymerization. In contrast, a five-membered cyclic carbonate, ethylene carbonate (EC), is difficult to undergo ring-opening polymerization especially under anionic conditions because of its stable cyclic structure. Under more active conditions using cationic catalysts, polymerization is accompanied with partial decarboxylation to afford linear polycarbonates having an ether unit $^{3,8}$ (Scheme 1).

Hitherto, there is little work on the synthesis of the co-

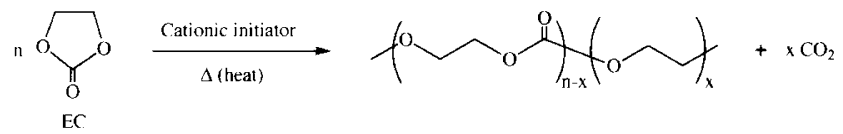

Scheme 1. EC homopolymerization accompanied with partial decarboxylation.

\footnotetext{
${ }^{\dagger}$ To whom correspondence should be addressed.
}

polymers of EC with lactones. Only Evans et al. ${ }^{6}$ reported the copolymerization of EC with $\varepsilon$-caprolactone (CL) without decarboxylation using reactive $\mathrm{Sm}$ (II) reagents. However, they could not obtain copolymers with number-average molecular weight $\left(M_{n}\right)$ more than 100000 and EC content more than $20 \mathrm{~mol} \%$, and mentioned nothing about the biodegradation of the copolymers. Thus, we describe first in this study the synthesis of the copolymers of EC with lactones using an organolanthanide (III) complex, $\left(\mathrm{C}_{5} \mathrm{Me}_{5}\right)_{2} \mathrm{SmMe}(\mathrm{THF})$, as catalyst, and report the biodegradation of the copolymers obtained. Yasuda et al. ${ }^{9}$ reported that this $\mathrm{Sm}$ (III) complex exhibits excellent catalysis for living polymerization of lactones, indicating the complex to be more reactive than $\mathrm{Sm}$ (II) complex used by Evans et al.

\section{EXPERIMENTAL}

\section{Materials}

Ethylene carbonate (EC ; Kanto Chemical Co., Inc.), $\varepsilon$ caprolactone (CL) and $\delta$-valerolactone (VL) (Tokyo Chemical Industry Co. Ltd.) were purchased commercially. EC in toluene was dried over anhydrous $\mathrm{Na}_{2} \mathrm{SO}_{4}$ and then $\mathrm{CaH}_{2}$ and recrystallized from toluene twice. Lactones (CL, VL) were dried over $\mathrm{CaH}_{2}$, distilled and kept on activated molecular sieves ( $4 \mathrm{~A}$ ) just before use. Solvents (toluene, $n$-hexane, tetrahydrofuran (THF), and diethylether) were dried over $\mathrm{CaH}_{2}$, refluxed with $\mathrm{Na} / \mathrm{K}$ alloy and finally distilled. These solvents were thoroughly degassed by trap-to-trap distillation just before use. The catalysts for polymerizations were $\mathrm{AlEt}_{3} /$ $\mathrm{H}_{2} \mathrm{O}(1 / 0.75)^{10}$ and organolanthanide complex $\left(\mathrm{C}_{5} \mathrm{Me}_{5}\right)_{2}$ $\mathrm{SmMe}(\mathrm{THF}){ }^{11}$

\section{Synthesis of Polymers}

All operations except the purification of polymers were conducted using Schlenk techniques under an argon at- 


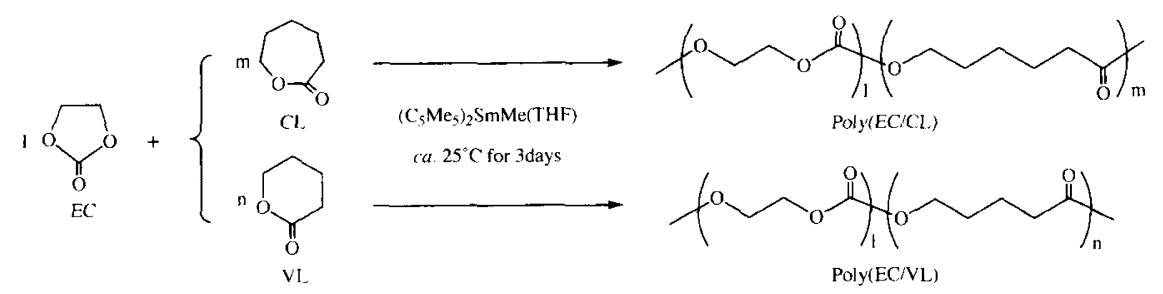

Scheme 2. Copolymerization of EC with CL(or VL) using the Sm( III)complex initiator.

Table I. Copolymerizaton ${ }^{\text {a }}$ of EC with lactone using $\left(\mathrm{C}_{5} \mathrm{Me}_{5}\right)_{2} \mathrm{SmMe}(\mathrm{THF})$ initiator

\begin{tabular}{|c|c|c|c|c|c|c|}
\hline \multirow{2}{*}{ Polymer } & \multicolumn{2}{|c|}{ EC/Lactone(molar ratio) } & \multirow{2}{*}{$\begin{array}{c}{[\mathrm{M}] /[\mathrm{I}]^{\mathrm{c}}} \\
(\text { molar ratio) }\end{array}$} & \multirow{2}{*}{$\frac{\text { Yield }}{\%}$} & \multirow{2}{*}{$\frac{M_{n}^{\mathrm{d}}}{10^{4}}$} & \multirow{2}{*}{$\frac{M_{w}{ }^{\mathrm{d}}}{M_{n}}$} \\
\hline & Feed & Observed $^{\mathrm{b}}$ & & & & \\
\hline \multirow{8}{*}{ Copoly(EC/CL) } & $10 / 90$ & $7 / 93$ & 600 & 90.8 & 15.7 & 1.94 \\
\hline & $15 / 85$ & $10 / 90$ & 800 & 87.2 & 17.5 & 2.00 \\
\hline & $20 / 80$ & $13 / 87$ & 800 & 73.5 & 16.2 & 1.82 \\
\hline & $30 / 70$ & $18 / 82$ & 800 & 76.5 & 19.5 & 2.06 \\
\hline & $40 / 60$ & $23 / 77$ & 800 & 73.7 & 19.2 & 1.81 \\
\hline & $50 / 50$ & $27 / 73$ & 1800 & 63.1 & 19.5 & 2.12 \\
\hline & $60 / 40$ & $31 / 69$ & 2000 & 49.0 & 14.9 & 1.87 \\
\hline & $70 / 30$ & $32 / 14 / 54^{\mathrm{h}}$ & 1500 & 29.5 & 4.66 & 1.81 \\
\hline \multirow{4}{*}{ Copoly(EC/VL) } & $20 / 80$ & $4 / 96$ & 800 & 66.0 & 14.3 & 1.69 \\
\hline & $40 / 60$ & $7 / 93$ & 1000 & 49.6 & 13.8 & 1.74 \\
\hline & $50 / 50$ & $10 / 90$ & 1500 & 48.7 & 14.6 & 1.98 \\
\hline & $60 / 40$ & $8 / 4 / 88^{h}$ & 2500 & 38.7 & 10.5 & 1.78 \\
\hline $\operatorname{Poly}(\overline{E C})^{e}$ & $100 / 0$ & $100 / 0$ & 50 & 42.8 & 0.28 & 1.30 \\
\hline $\operatorname{Poly}(\mathrm{CL})^{\mathrm{f}}$ & $0 / 100$ & $0 / 100$ & 200 & 81.4 & 15.6 & 1.87 \\
\hline $\operatorname{Poly}(C L)^{g}$ & $0 / 100$ & $0 / 100$ & 500 & 92.0 & 17.8 & 1.26 \\
\hline $\operatorname{Poly}(\mathrm{VL})^{\mathrm{f}}$ & $0 / 100$ & $0 / 100$ & 200 & 85.6 & 13.3 & 1.60 \\
\hline
\end{tabular}

${ }^{\mathrm{a}}$ Polymerized at $c a \cdot 25^{\circ} \mathrm{C}$ for 3 days in toluene. ${ }^{\mathrm{b}, \mathrm{d}}$ Determined by ${ }^{1} \mathrm{H}$ NMR and GPC, respectively. ${ }^{\mathrm{c}}[\mathrm{M}] /[\mathrm{I}]=[\mathrm{Monomer}] /[$ Initiator $] .{ }^{\mathrm{e}} \mathrm{Po}-$ lymerized at $150^{\circ} \mathrm{C}$ for 3 days ; initiator, $\mathrm{Zr}\left(\mathrm{OC}_{3} \mathrm{H}_{7}\right)_{4}$. ${ }^{\mathrm{f}}$ Polymerized at $60^{\circ} \mathrm{C}$ for 1 day ; initiator, $\mathrm{AlEt}_{3} / \mathrm{H}_{2} \mathrm{O}(1: 0.75)$. ${ }^{\mathrm{g}}$ Polymerized at $00^{\circ} \mathrm{C}$ for $4 \mathrm{~h}$; initiator, $\left(\mathrm{C}_{5} \mathrm{Me}_{5}\right)_{2} \mathrm{SmMe}(\mathrm{THF})$. ${ }^{\mathrm{h}}$ Molar ratio of EC/Ether( derived from decarboxylation of EC )/Lactone.

mosphere.

The copolymerizations of EC with lactones were initiated by the $\mathrm{Sm}$ (III) complex $\left[\left(\mathrm{C}_{5} \mathrm{Me}_{5}\right)_{2} \mathrm{SmMe}(\mathrm{THF})\right]$ (Scheme 2). EC (0.28 g, $3.19 \mathrm{mmol})$, CL (0.794 mL, 7.45 $\mathrm{mmol})(\mathrm{EC} / \mathrm{CL}=30 / 70$ in molar ratio), and the initiator $\left(13.3 \times 10^{-3} \mathrm{mmol}\right)$ together with dry-degassed toluene $(5.0 \mathrm{~mL})$ were placed in a $20 \mathrm{~mL}-\mathrm{Schlenk}$ tube and the mixture was warmed to $c a .25^{\circ} \mathrm{C}$ for 3 days. The resulting mixture was dissolved in chloroform, and poured into $n$-hexane/diethylether ( $4 / 1$ in volume) for precipitating the copolymer. The copolymer obtained was washed with $n$-hexane, and dried in vacuo at the ambient temperature. Table I shows the polymerization conditions and results.

The homopolymerizations of lactones were initiated by $\mathrm{AlEt}_{3} / \mathrm{H}_{2} \mathrm{O}^{10}$ and those of EC were carried out using initiators such as $\mathrm{AlEt}_{3} / \mathrm{H}_{2} \mathrm{O}, \mathrm{ZnEt}_{2} / \mathrm{H}_{2} \mathrm{O}$, distannoxane, ${ }^{12}$ and $\mathrm{Zr}\left(\mathrm{OC}_{3} \mathrm{H}_{7}\right)_{4}{ }^{8} \mathrm{We}$ obtained EC homopolymer [poly (EC)] only when using a $\mathrm{Zr}\left(\mathrm{OC}_{3} \mathrm{H}_{7}\right)_{4}$. As shown in ${ }^{1} \mathrm{H}$ NMR spectrum (Figure 1), the resulting poly(EC) included the ether unit, suggesting partial (ca. 50\%) decarboxylation during the polymerization. Yield and molecular weight of poly $(\mathrm{EC})$ (viscous liquid) were rather low (see Table I). Hence, we did not use this type of ho- mopolymer in the following experiments.

\section{Characterization of Polymers}

The number-average molecular weight $\left(M_{n}\right)$ and polydispersity $\left(M_{w} / M_{n}\right)$ of polymers were determined by gel permeation chromatography (GPC) at column oven temperature $40^{\circ} \mathrm{C}$ on a Tosoh GPC system 8010 equipped with four TSKgel columns $\left(\mathrm{G} 2000 \mathrm{H}_{\mathrm{HR}}+\mathrm{G} 3000 \mathrm{H}_{\mathrm{HR}}+\mathrm{G}\right.$ $4000 \mathrm{H}_{\mathrm{HR}}+\mathrm{G} 5000 \mathrm{H}_{\mathrm{HR}}$ ) using a differential refractometer, calibrating with standard polystyrenes. Chloroform was used as eluent at the flow rate of $1.0 \mathrm{~mL} \mathrm{~min}^{-1}$.

The compositions of copolymers were analyzed by ${ }^{1} \mathrm{H}$ NMR spectra measured on a JEOL JNM-LA 400 spectrometer. The randomness of copolymers was estimated from ${ }^{1} \mathrm{H}$ NMR spectra.

The thermal properties of polymers, glass transition temperature $\left(T_{\mathrm{g}}\right)$, melting temperature $\left(T_{\mathrm{m}}\right)$, and heat of fusion $\left(\Delta H_{\mathrm{m}}\right)$ were measured by differential scanning calorimetry (DSC) on a Seiko SSC5100 DSC22C apparatus. The polymer samples were scanned from -100 to $120^{\circ} \mathrm{C}$ at a heating rate of $10^{\circ} \mathrm{C} \mathrm{min}^{-1}$ under nitrogen stream. $T_{\mathrm{m}}$ and $\Delta H_{\mathrm{m}}$ were determined in the first heating, while $T_{\mathrm{g}}$ was determined in the second heating. 


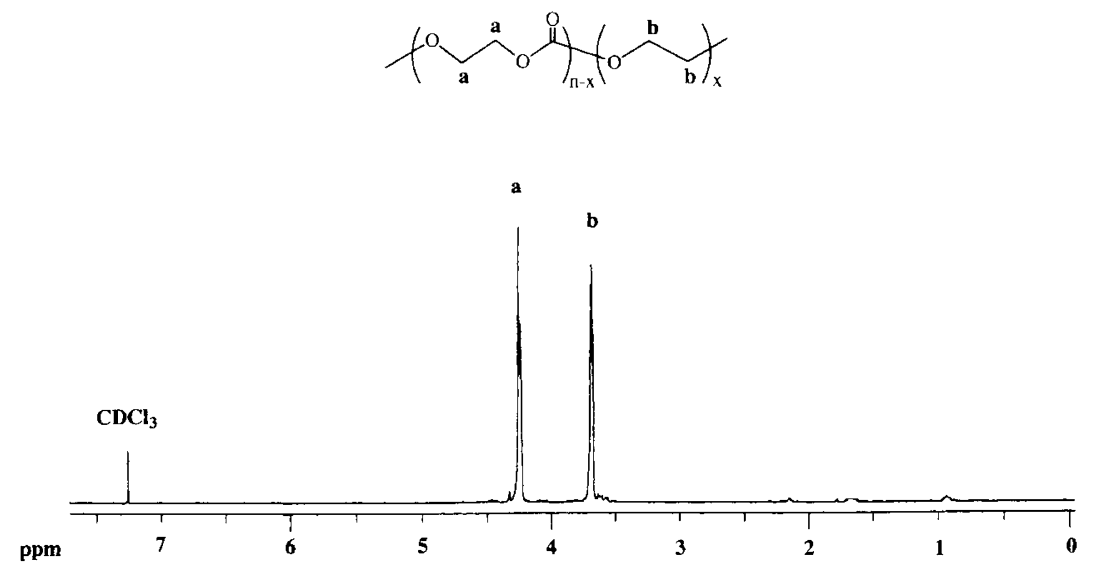

Figure 1. ${ }^{1} \mathrm{H}$ NMR spectrum of poly(EC) containing the ether unit.

\section{Biodegradations of Polymers}

The biodegradability of polymer films was estimated in enzymes, activated sludge, and seawater. All sample films $(100 \pm 10 \mu \mathrm{m}$ in thickness) were prepared by solvent casting method.

Enzymatic Degradation. The enzymes were cholesterol esterase (Wako Pure Chemical Industries, Ltd., specific activity $20 \mathrm{IU} \mathrm{mg}^{-1}$ ) and lipoprotein lipase (E. Merck Darmstat, specific activity $200 \mathrm{IU} \mathrm{mg}^{-1}$ ) from Pseudomonas sp. Tokiwa et al. ${ }^{12}$ recently reported that lipoprotein lipase degrades aliphatic polycarbonates. The polymer films sealed in a polyethylene mesh sheet (mesh size $1 \times 1 \mathrm{~mm}$ ) were placed in vial tubes containing enzyme ( 1 unit $\mathrm{mg}^{-1}$-polymer) and buffer solution. The tubes were incubated at $37^{\circ} \mathrm{C}$ in a water bath shaker. The buffered enzyme solution was replaced every $40 \mathrm{~h}$ to maintain enzyme activity. Good's buffers, TES $\{N$-tris(hydroxymethyl)methyl-2-aminoethanesulfonic acid, $\mathrm{pH}$ 7.4 , for the esterase $\}$ and Tricine $\{N$-[tris(hydroxymethyl)methyl]glycine, $\mathrm{pH}$ 8.0, for the lipase) were used. Distilled and deionized water was used for enzymatic degradation tests.

Degradation by Activated Sludge. The degradation of polymer samples (sealed in a polyethylene mesh sheet) by activated sludge was carried out in a $20 \mathrm{~L}$ tank containing aerated sludge at $25^{\circ} \mathrm{C}$. The sludge was provided by Higashi-Hiroshima Wastewater Treatment Plant, MLSS ca. $2800 \mathrm{ppm}, \mathrm{pH}$ ca. 6.

Degradation in Seawater. The degradation of polymer films in seawater was carried out by sinking the films in Takehara Bay of the Inland Sea at $10-15^{\circ} \mathrm{C}$ (from Dec. to Feb.). The films were placed in a stainless mesh cage and sunk to a depth of $1.5 \mathrm{~m}$ in the crawl (located in the Bay, and attached to Faculty of Applied Biological Science, Hiroshima University).

In all tests, the polymer samples were washed with water at a definite time, and dried to constant weight in vacuo. The degradability was evaluated from the changes in weight loss, molecular weight, composition, and thermal properties of the polymer before and after degradation.

\section{RESULTS AND DISCUSSION}

\section{Synthesis and Characterization of Polymers}

Table I shows polymerization results of EC/lactone copolymers initiated by $\left(\mathrm{C}_{5} \mathrm{Me}_{5}\right)_{2} \mathrm{SmMe}(\mathrm{THF})$, together with data for homopolymers. Under fixed conditions (25 ${ }^{\circ} \mathrm{C}$ for $3 \mathrm{~d}$ ), the molar concentration ratio ([M]/[I]) of monomer to initiator was changed to get the best yield and highest molecular weight of the copolymer. As seen from Table I, the yield of the copolymer decreased with increase of EC content, while molecular weight remained high enough $\left(M_{n} \geq 140000\right)$. The amount of EC incorporated into the copolymer was much smaller than that of EC fed particularly at higher EC concentrations. Evans et al. ${ }^{6}$ pointed out that EC is not polymerized by the reactive $\mathrm{Sm}$ (II ) reagents such as $\left(\mathrm{C}_{5} \mathrm{Me}_{5}\right)_{2} \mathrm{Sm}(\mathrm{THF})_{2}$, but polymerized in the presence of CL/Sm( II ) system. EC monomer can be incorporated into a poly(CL) growing chain and the repeated incorporation of EC unit is inhibited. In particular for EC/VL system, only a little EC monomer was incorporated into the copolymer, resulting in a lower yield. There are large differences in the incorporation of EC and yield for EC/CL and EC/VL copolymers, owing to stability difference in growing chains of the two systems. We could not obtain EC/lactone copolymers without decarboxylation, when we used EC concentrations higher than the feeding ratios of 60 / 40 for EC/CL and 50/50 for EC/VL systems (Table I). Figure 2 shows the ${ }^{1} \mathrm{H}$ NMR spectrum of EC/CL( $\left.=10 / 90\right)$ copolymer. No peak of the ether unit around $3.7 \mathrm{ppm}$ was observed, suggesting that no decarboxylation occurs during the polymerization. $\alpha$ - and $\varepsilon$-methylene proton signals of CL unit are sensitive to adjacent comonomer units, ${ }^{13}$ and split into two peaks (b, f), indicating random arrangement of the CL unit in this copolymer.

The thermal properties of EC/lactone copolymers are given in Table II. The resulting EC homopolymer includes the ether linkage arising from decarboxylation of EC unit, and is a viscous liquid polymer with a low molecular weight $\left(M_{n}=2800\right)$. Hence, the thermal properties of this homopolymer were not measured. Single values of glass transition and melting temperatures $\left(T_{\mathrm{g}}\right.$ and $T_{\mathrm{m}}$ ) were observed for individual copolymers and their 

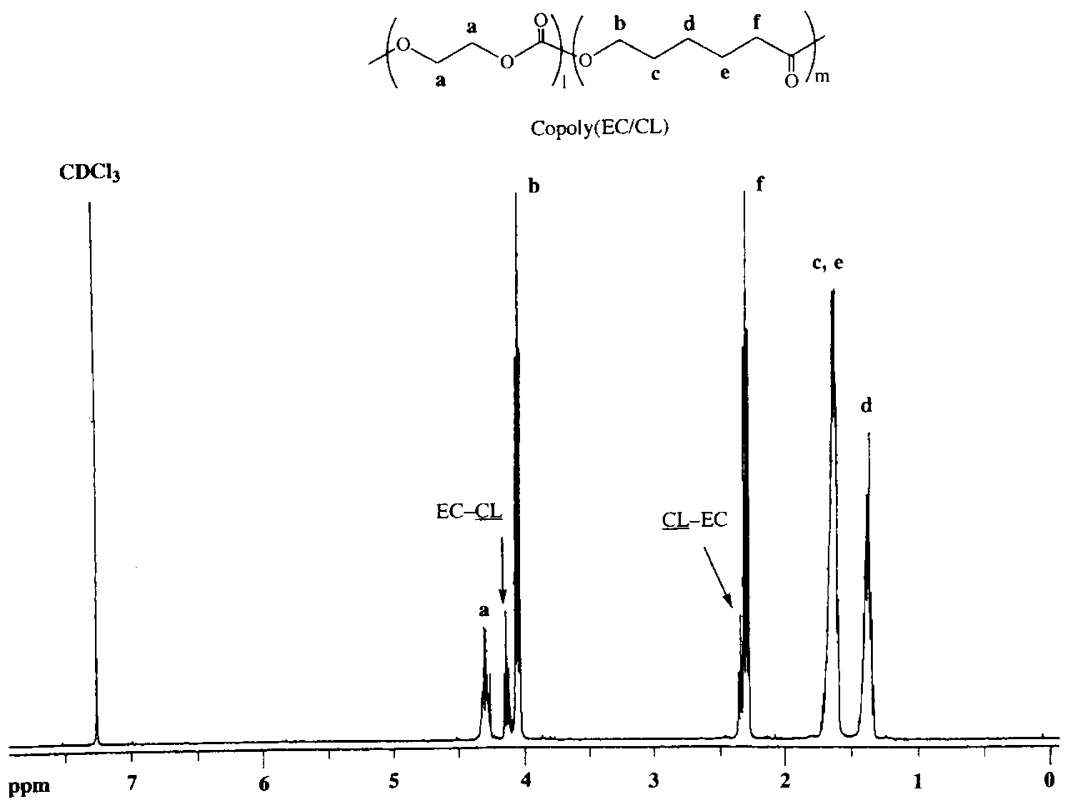

Figure 2. ${ }^{1} \mathrm{H}$ NMR spectrum of the $\mathrm{EC} / \mathrm{CL}(=10 / 90)$ copolymer.

Table II. Thermal properties of EC/lactone copolymers

\begin{tabular}{|c|c|c|c|c|c|}
\hline Polymer & $\begin{array}{l}\text { EC/Lactone } \mathrm{a}^{\mathrm{a}} \\
\text { (molar ratio) }\end{array}$ & $\frac{M_{n}{ }^{\mathrm{b}}}{10^{4}}$ & $\frac{T_{\mathrm{g}}^{\mathrm{c}}}{{ }^{\circ} \mathrm{C}}$ & $\frac{T_{\mathrm{m}}{ }^{\mathrm{c}}}{{ }^{\circ} \mathrm{C}}$ & $\frac{-\Delta H_{\mathrm{m}}{ }^{\mathrm{c}}}{\mathrm{J} \mathrm{g}^{-1}}$ \\
\hline \multirow{7}{*}{ Copoly(EC/CL) } & $7 / 93$ & 15.7 & -62.7 & 51.6 & 77.4 \\
\hline & $10 / 90$ & 17.5 & -60.7 & 49.6 & 64.8 \\
\hline & $13 / 87$ & 16.2 & -55.9 & 46.7 & 59.4 \\
\hline & $18 / 82$ & 19.5 & -55.3 & 38.4 & 43.2 \\
\hline & $23 / 77$ & 19.2 & -53.5 & 31.4 & 21.0 \\
\hline & $27 / 73$ & 19.5 & -49.4 & 30.9 & 0.8 \\
\hline & $31 / 69$ & 14.9 & -48.6 & N.D. & - \\
\hline \multirow{3}{*}{ Copoly(EC/VL) } & $4 / 96$ & 14.3 & -59.3 & 50.4 & 79.6 \\
\hline & $7 / 93$ & 13.8 & -54.4 & 48.2 & 69.0 \\
\hline & $10 / 90$ & 14.6 & -52.3 & 45.9 & 61.4 \\
\hline Poly(CL) & $0 / 100$ & 15.6 & -63.0 & 60.9 & 96.3 \\
\hline Poly(VL) & $0 / 100$ & 13.3 & -59.9 & 58.9 & 89.8 \\
\hline
\end{tabular}

a, b.c Determined by ${ }^{1} \mathrm{H}$ NMR, GPC, and DSC, respectively. N. D. : Not detected.

values varied with polymer composition. All the copolymers thus have random sequences and semicrystalline nature except the EC/CL (=31/69) copolymer.

\section{Biodegradation of Polymers}

Enzymatic Degradation. Before enzymatic degradation, hydrolytic degradation of the copolymers was carried out in buffer solutions containing no enzyme. However, degradability was hardly discernible for each polymer, i.e., the weight loss of the polymer after $200 \mathrm{~h}$ degradation was only a few \%. Figure 3 shows the enzymatic degradations of EC/CL copolymers by lipoprotein lipase (a) and by cholesterol esterase (b). Generally, the lower the crystallinity $\left(\Delta H_{\mathrm{m}}\right)$ is, the higher is the degradability. Nevertheless, maximum degradation in both enzyme solutions was observed for the $\operatorname{EC} / \mathrm{CL}(=13 / 87)$ co- polymer having an intermediate crystallinity $\left(-\Delta H_{\mathrm{m}}=\right.$ $59.4 \mathrm{~J} \mathrm{~g}^{-1}$ ). The polymer should have some crystallinity for being degraded. It is thought that the crystalline (or hydrophobic) domain on the polymer surface is the scaffolding for the enzyme adsorption, resulting in enzymatic degradation. ${ }^{14,15}$ Greater degradability of the copolymer by lipoprotein lipase was observed than that by cholesterol esterase, probably due to the higher substrate specificity of the lipase for the carbonate units than that of the esterase. ${ }^{12}$ Maximum degradation of EC/VL copolymers was obtained at the EC/VL ratio of $10 / 90$ (Figure 4). If the copolymers containing more EC unit can be prepared without decarboxylation, the degradability will decrease with increasing EC content in the region of EC/NL>10/90.

To elucidate enzymatic degradability, changes in composition, molecular weight, and thermal properties of the $\mathrm{EC} / \mathrm{CL}(=13 / 87)$ copolymer were measured before and after degradation by lipoprotein lipase (Table III). As seen from this table, the composition (EC/CL ratio), molecular weight $\left(M_{n}\right)$ and its distribution $\left(M_{w} / M_{n}\right)$ did not change very much, indicating uniform degradation from the polymer film surface. The thermal properties $\left(T_{\mathrm{m}}\right.$ and $\left.\Delta H_{\mathrm{m}}\right)$ of the copolymer increased with degradation period. This suggests that the enzymatic degradation occurs more easily at the amorphous part of the copolymer than the crystalline one.

We examined the effects of the methylene chain length of cyclic carbonates (CC) on the thermal properties and enzymatic degradation of the copolymers. Table IV shows some properties of CC/CL copolymers, i.e., EC/ CL copolymers and trimethylene carbonate $(\mathrm{TMC}) / \mathrm{CL}(=$ 19/81) copolymer. ${ }^{10}$ The table indicates that the thermal properties (viz., $T_{\mathrm{m}}$ and $\Delta H_{\mathrm{m}}$ values) of the $\mathrm{EC} / \mathrm{CL}(=18 /$ 82) copolymer are smaller than those of the TMC/CL(= 19/81) copolymer. Thus, comparable thermal properties were obtained by less introduction $(10 \mathrm{~mol} \%)$ of EC unit than that (19 mol\%) of TMC. As mentioned previously, 

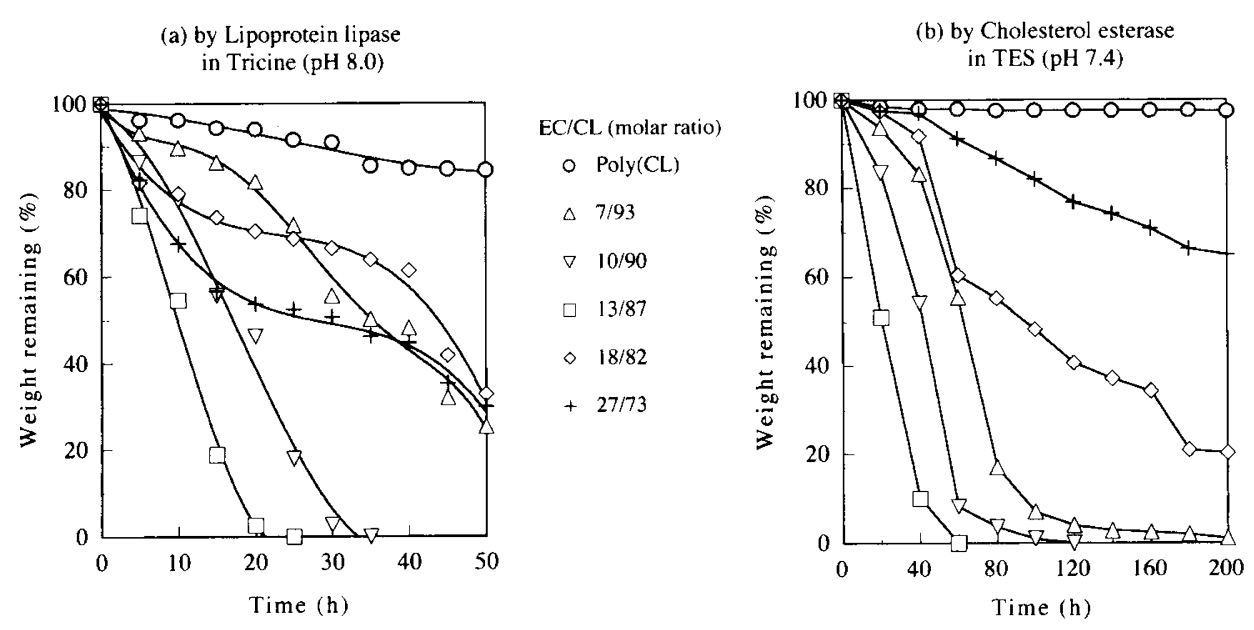

Figure 3. Enzymatic degradation of the EC/CL copolymers by the lipase (a) and the esterase (b) at $37^{\circ} \mathrm{C}$.
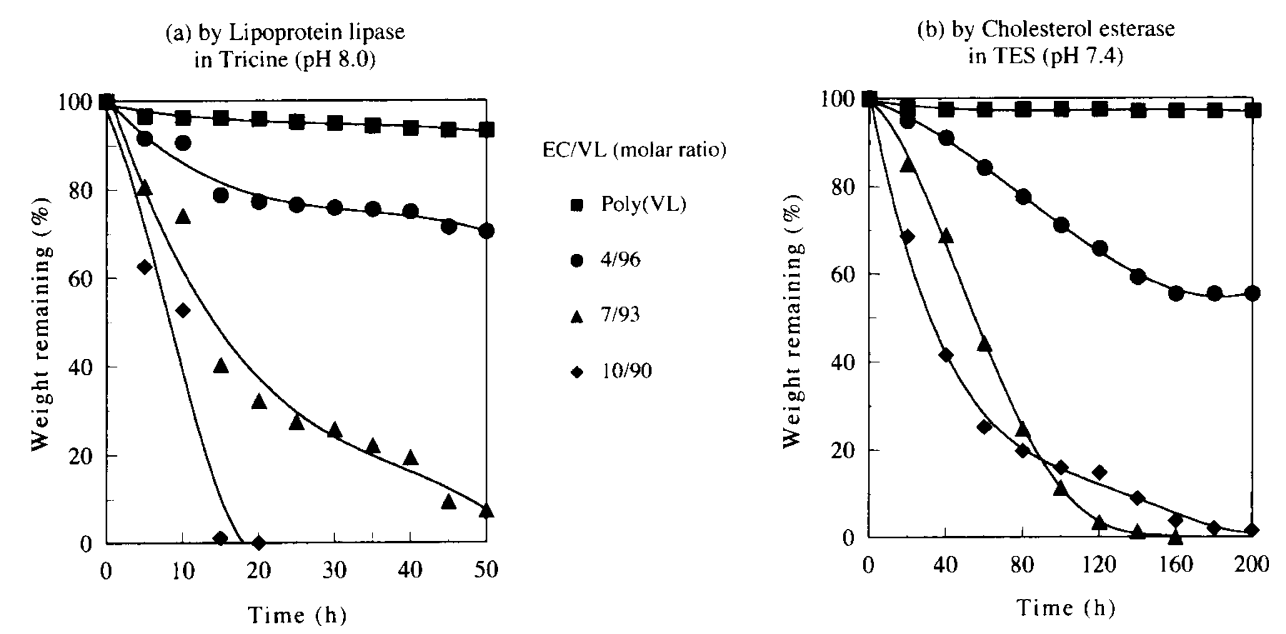

Figure 4. Enzymatic degradation of the EC/VL copolymers by the lipase (a) and the esterase (b) at $37^{\circ} \mathrm{C}$.

Table III. Changes in properties of EC/CL $(=13 / 87)$ copolymer upon degradation by lipoprotein lipase

\begin{tabular}{ccccccccc}
\hline $\begin{array}{c}\text { Degradation } \\
\text { time/h }\end{array}$ & $\begin{array}{c}\text { Weight } \\
\text { remaining/\% }\end{array}$ & $\begin{array}{c}\mathrm{EC} / \mathrm{CL}^{\mathrm{a}} \\
(\text { molar ratio) }\end{array}$ & $\frac{M_{n}{ }^{\mathrm{b}}}{10^{4}}$ & $\frac{M_{w}{ }^{\mathrm{b}}}{M_{n}}$ & $\frac{T_{\mathrm{g}}{ }^{\mathrm{c}}}{{ }^{\circ} \mathrm{C}}$ & $\frac{T_{\mathrm{m}}{ }^{\mathrm{c}}}{{ }^{\circ} \mathrm{C}}$ & $\frac{-\Delta H_{\mathrm{m}}{ }^{\mathrm{c}}}{\mathrm{Jg}^{-1}}$ \\
\hline 0 & 100 & $12.6 / 87.4$ & 16.2 & 1.82 & -55.9 & 46.7 & 59.4 \\
2 & 93 & $12.5 / 87.5$ & 14.2 & 1.77 & -56.4 & 48.9 & 66.0 \\
4 & 75 & $12.4 / 87.6$ & 14.1 & 1.88 & -56.3 & 49.1 & 67.9 \\
10 & 55 & $12.1 / 87.9$ & 12.2 & 1.90 & -57.0 & 49.3 & 72.0 \\
\hline
\end{tabular}

${ }^{\mathrm{a}, \mathrm{b}, \mathrm{c}}$ Determined by ${ }^{1} \mathrm{H}$ NMR, GPC, and DSC, respectively.

Table IV. Comparison of some properties of CC/CL copolymers

\begin{tabular}{|c|c|c|c|c|c|}
\hline Polymer & $\begin{array}{c}\mathrm{CC} / \mathrm{CL}^{\mathrm{a}} \\
\text { (molar ratio) }\end{array}$ & $\frac{M_{n}^{\mathrm{b}}}{10^{4}}$ & $\frac{T_{\mathrm{g}}^{\mathrm{c}}}{{ }^{\circ} \mathrm{C}}$ & $\frac{T_{\mathrm{m}}{ }^{\mathrm{c}}}{{ }^{\circ} \mathrm{C}}$ & $\frac{-\Delta H_{\mathrm{m}}{ }^{\mathrm{c}}}{\mathrm{Jg}^{-1}}$ \\
\hline \multirow[t]{2}{*}{ Copoly(EC/CL) } & $10 / 90$ & 17.5 & -60.7 & 47.1 & 64.8 \\
\hline & $18 / 82$ & 19.5 & -55.3 & 38.4 & 43.2 \\
\hline Copoly(TMC/CL) & $19 / 81$ & 18.9 & -60.7 & 50.7 & 58.1 \\
\hline
\end{tabular}

the repeated incorporation of EC unit into the copolymer is very hard. The resulting copolymers thus exhibit higher randomness of EC/CL copolymers compared with TMC/CL copolymers. This leads to decrease in crystallinity $\left(\Delta H_{\mathrm{m}}\right)$ of EC/CL copolymers.

Figure 5 shows the enzymatic degradations of the above CC/CL copolymers by lipoprotein lipase. The degradability of the EC/CL $(=10 / 90)$ copolymer is considerably higher than that of the TMC/CL $(=19 / 81)$ copolymer. Since these two copolymers have nearly the same thermal properties \{especially $\Delta H_{\mathrm{m}}$ (crystallinity), see Table IV \}, there is little difference in the adsorbability of the enzyme, and hence little difference in degradability. One 


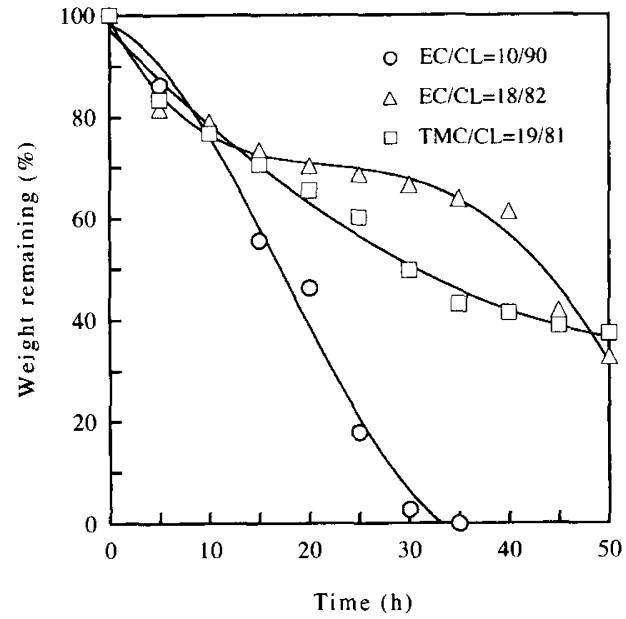

Figure 5. Enzymatic degradation of the CC/CL copolymers by lipoprotein lipase in Tricine buffer $\left(\mathrm{pH} 8.0,37^{\circ} \mathrm{C}\right)$.

possible reason is that the hydrophilicity of the $\mathrm{CC}$ unit in the copolymer affects the enzymatic degradation. Basically, enzymes are water soluble, and therefore the activity of catalytic sites is higher in hydrophilic surroundings than in hydrophobic ones. The EC unit should be more hydrophilic than TMC unit since the former is shorter by one methylene length. However, a higher EC content results in lower enzymatic degradability as observed for the EC/CL $(=18 / 82)$ copolymer due to the decrease in its crystallinity. Thus, the enzymatic degradation of polymers is affected by many factors such as their thermal properties and hydrophilicity, and the substrate specificity of the enzymes. Less incorporation of EC unit into copolymers compared with TMC unit leads to polymers having better biodegradability.

Degradations in Activated Sludge and Seawater. Considering that plastics are often discarded illegally in the environment, it is very important to examine the biodegradation of synthetic polymers in such environments as activated sludge and seawater. Figure 6 shows the biodegradation of EC/lactone copolymers by activated sludge. The degradability of EC/CL copolymers resembles that by enzymes, but the maximum degradation is obtained at slightly higher EC/CL ( $c f$. Figures 3 and $6 a$ ), wherein all EC/CL copolymers degraded completely within 50 days. The biodegradation of EC/VL copolymers is little detected up to $c a$. 70 days, thereafter followed by slow degradation compared with EC/CL copolymers (Figure 6b), presumably due to the slower degradation of poly(VL) than poly(CL). Similar results were observed for the copolymers of an optically active lactone $((R)$ MOHEL) with CL. ${ }^{16}$ The biodegradation of EC/CL copolymers in seawater is given in Figure 7. Degradability in seawater shows much the same tendency as that in activated sludge, indicating that similar bacteria exist in these two environments. However, the degradation rate in seawater is a little slower than that by activated sludge.

We prepared EC/lactone copolymers without decarboxylation of EC unit using $\left(\mathrm{C}_{5} \mathrm{Me}_{5}\right)_{2} \mathrm{SmMe}(\mathrm{THF})$ as initiator. $\mathrm{EC} / \mathrm{CL}(\leq 10 / 90)$ copolymers serve as good biodegradable polymers with comparable thermal properties (a) $\mathrm{EC} / \mathrm{CL}$ copolymers

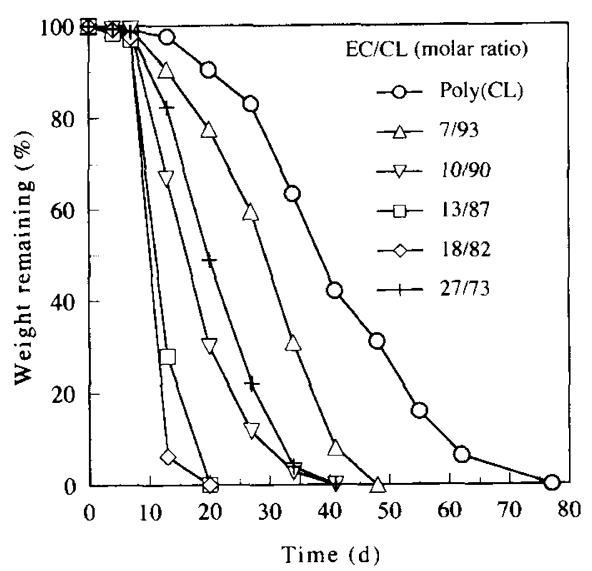

(b) EC/VL copolymers

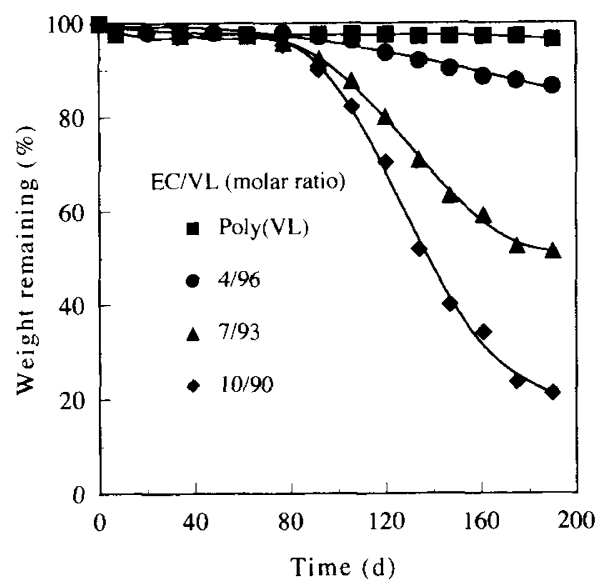

Figure 6. Biodegradation of EC/lactone copolymers by activated sludge ( $\mathrm{pH} c a \cdot 6 \cdot 0,25^{\circ} \mathrm{C}$ ).

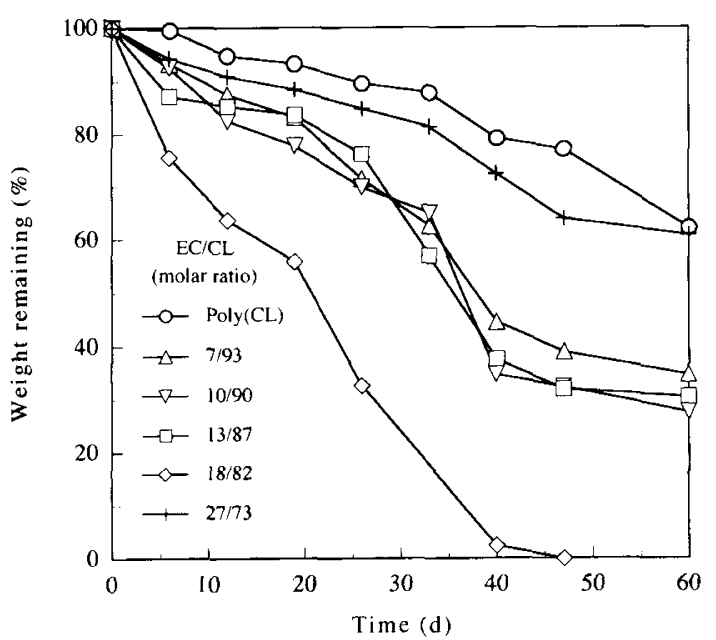

Figure 7. Biodegradation of EC/CL copolymers in seawater ( $\mathrm{pH}$ ca. $8.1,10^{-}-15^{\circ} \mathrm{C}$ ).

to $\operatorname{poly}(\mathrm{CL})$.

Acknowledgment. This work was supported by a Grant-in-Aid for Scientific Research on Priority Area, "Sustainable Biodegradable Plastics", No.11217211 
(1999) from the Ministry of Education, Science, Sports and Culture (Japan).

\section{REFERENCES}

1. I. Mita, Ed., "Concise Encyclopedia of Polymer Science and Engineering", Maruzen Co., Tokyo, 1994, p 1040.

2. B. Wurm, H. Höcker, and H. Keul, Macromolecules, 25, 2977 (1992).

3. H. R. Kricheldorf and B. Weegen-Schulz, Macromolecules, 26, 5991 (1993).

4. T. Ariga, T. Takata, and T. Endo, Macromolecules, 26, 7106 (1993).

5. T. Ariga, T. Takata, and T. Endo, J. Polym. Sci., Part A: Polym. Chem., 31, 581 (1993).

6. W. J. Evans and H. Katsumata, Macromolecules, 27, 4011 (1994).

7. M. Akatsuka, T. Aida, and S. Inoue, Macromolecules, 28, 1320 (1995).
8. L. Vogdanis and W. Heitz, Makromol. Chem. Rapid Commun., 7, 543 (1986).

9. M. Yamashita, Y. Takemoto, E. Ihara, and H. Yasuda, Macromolecules, 29, 1798 (1996)

10. H. Shirahama, A. Kanetani, and H. Yasuda, Yukagaku ( $J$. Jpn. Oil Chem. Soc.), 47, 1251 (1998).

11. W. J. Evans, L. R. Chamberlain, T. A. Ulibarri, and J. W. Ziller, J. Am. Chem. Soc., 110,6423 (1988).

12. T. Suyama and Y. Tokiwa, Enzyme Microb. Technol., 20, 122 (1997).

13. P. J. A. in't Veld, Y. Wei-ping, R. Klap, P. J. Dijkstra, and J. Feijen, Makromol. Chem., 193, 1927 (1992).

14. H. Abe, I. Matsubara, and Y. Doi, Macromolecules, 28, 844 (1995).

15. H. Shirahama, K. Kojima, and H. Yasuda, Yukagaku (J. Jpn. Oil Chem. Soc .), 47, 73 (1998).

16. H. Shirahama, K. Mizuma, Y. Kawaguchi, M. Shiomi, and H. Yasuda, Kobunshi Ronbunshu (Jpn. J. Polym. Sci. Technol.), 50, 821 (1993). 